\title{
Journal of Nephropathology
}

\section{Acute kidney injury in COVID-19; a review on current knowledge}

\author{
Elahe Aleebrahim-Dehkordi ${ }^{1,2}{ }^{\circledR}$, Ali Reyhanian ${ }^{3}{ }^{\circledR}$, Shirin Saberianpour ${ }^{4}{ }^{\circledR}$, Ali Hasanpour-Dehkordi ${ }^{5,6^{*}}$ \\ ${ }^{1}$ Young Researchers and Elite Club, Shahrekord Branch, Islamic Azad University, Shahrekord, Iran \\ ${ }^{2}$ Medical Plants Research Center, Basic Health Sciences Institute, Shahrekord University of Medical Sciences, Shahrekord, Iran \\ ${ }^{3}$ Student Research Committee, Shahrekord University of Medical Sciences, Shahrekord, Iran \\ ${ }^{4}$ Department of Molecular Medicine, School of Advanced Medical Sciences, Tabriz University of Medical Sciences, Tabriz, Iran \\ ${ }^{5}$ Social Determinants of Health Research Center, School of Allied Medical Sciences, Shahrekord University of Medical Sciences, \\ Shahrekord, Iran \\ ${ }^{6}$ Nickan Research Institute, Isfahan, Iran
}

\begin{tabular}{|c|c|}
\hline ARTICLE INFO & ABSTRACT \\
\hline $\begin{array}{l}\text { Article type: } \\
\text { Review }\end{array}$ & $\begin{array}{l}\text { Coronaviruses are a large family of viruses that can cause a variety of diseases in humans. Some } \\
\text { coronaviruses cause only mild illnesses like the common cold. While, some coronaviruses such }\end{array}$ \\
\hline $\begin{array}{l}\text { Article history: } \\
\text { Received: } 25 \text { March } 2020 \\
\text { Accepted: } 10 \text { April } 2020 \\
\text { Published online: } 17 \text { April } 2020\end{array}$ & $\begin{array}{l}\text { (MERS-CoV) have, in recent years, been able to cause severe respiratory involvement (pneumonia), } \\
\text { leading to death in several patients. By identifying the genomic sequence of the new human } \\
\text { coronavirus SARS-CoV-2 (severe acute respiratory syndrome coronavirus } 2 \text { ) it has been revealed } \\
\text { that it belongs to the beta coronavirus genus. COVID-19 appears to be transmitted by a mechanism }\end{array}$ \\
\hline $\begin{array}{l}\text { Keywords: } \\
\text { Acute kidney injury, } \\
\text { Infection, } \\
\text { Coronavirus, } \\
\text { COVID-19, } \\
\text { Severe acute respiratory } \\
\text { syndrome coronavirus } 2\end{array}$ & $\begin{array}{l}\text { similar to the influenza virus via person to person, sneezing coughing, or contact with the secretions } \\
\text { of infected patients. Early symptoms of these respiratory viruses include fever, cough, and shortness } \\
\text { of breath, with an incubation period of } 2-14 \text { days. SARS-CoV-2 is an acute respiratory disease } \\
\text { that initially causes lung damage. SARS-CoV-2 can affect other organs, including the kidneys. } \\
\text { Kidney damage may be caused by alterations that occur during coronavirus infection. It seems that } \\
\text { low-oxygen delivery to tissues like the kidney in the setting of this disease may lead to ischemic } \\
\text { damage of the kidney. Considering the importance of the kidneys, as one, this review study aimed } \\
\text { to investigate the effect of the new coronavirus on the kidneys and its role in the development of } \\
\text { renal failure. }\end{array}$ \\
\hline
\end{tabular}

Implication for health policy/practice/research/medical education:

Acute kidney injury in patients with COVID-19 can be the result of specific pathogenic conditions, including cytokine release syndrome. Please cite this paper as: Aleebrahim-Dehkordi E, Reyhanian A, Saberianpour Sh, Hasanpour-Dehkordi A. Acute kidney injury in COVID-19; a review on current knowledge. J Nephropathol. 2020;9(4):e31. DOI: 10.34172/jnp.2020.31.

\section{Introduction}

In early December 2019, a number of pneumonia cases of unknown origin emerged in Wuhan, China. Most of these patients had exposure to the Huanan Seafood Wholesale Market selling many species of live animals. The disease had fast spread to other parts of China, and globally to many countries (1). With rapid spread of the disease in China and then all over the world, the new coronavirus scientifically named SARS-CoV-2 (severe acute respiratory syndrome coronavirus 2) and the resulting illness known as COVID-19 caused a great deal of anxiety and panic worldwide.

Rapidly increasing number of COVID-19 cases and subsequent deaths globally spurred WHO to declare a Public Health Emergency of International Concern on January 30, 2020, which was upgraded to the declaration of Pandemic on March 11, 2020 (2,3). Phylogenetically, the virus belongs to the same genus as the severe acute respiratory syndrome coronavirus (SARS-CoV) and Middle East respiratory syndrome coronavirus (MERS$\mathrm{CoV})(4,5)$. COVID-19 is a respiratory disease; therefore, it usually affects the lungs first. Early symptoms include 
fever, cough, and shortness of breath. The incubation period of COVID19 seems to be 2-14 days (6). The severity of COVID-19 ranges from no symptoms to severe or sometimes fatal disease. According to reports, $81 \%$ of COVID-19 patients in China had mild symptoms while others had severe or critical involvement (7-9). Of 41 confirmed cases of SARS-CoV-2 infection admitted to Wuhan, China hospital, it was found that fever (98\%), cough $(76 \%)$, shortness of breath $(55 \%)$, and muscle pain and fatigue $(44 \%)$ were the most common clinical symptoms (3). In addition, symptoms of the upper respiratory tract such as sore throat and runny nose to a lesser degree were observed in patients with COVID-19. Unlike SARS-CoV, gastrointestinal symptoms such as diarrhea are rarely seen in patients with SARS-CoV-2 $(3,7)$. According to a recent study, the main route of transmission of SARS-CoV2 (COVID-19) is through inhalation of respiratory droplets and close contact with the infected patients (3). The highest rate of virus transmission is seen when the person has clinical symptoms (10). However, some patients are capable to transmit the infection to others before the appearance of clinical symptoms. (10). Lungs are the primary organ affected by COVID-19; however, in severe cases, other organs can also be affected. Other organ dysfunctions are also seen in people severely affected by COVID-19. This organ damage is not always directly caused by infection but may be caused by the body's response to infection. Some admitted patients with COVID19 also have acute kidney damage, sometimes requiring hemodialysis. The damage has also occurred in other human coronaviruses including SARS-CoV and MERS-CoV (11-13). Some viral diseases (including human chiropractors) can affect the kidney function during severe infections (14). Considering the importance of the kidney, this review study aimed to investigate the effect of the new coronavirus (SARS-CoV2) on the kidney and its role in the development of renal failure.

\section{Acute kidney injury}

Acute kidney injury (AKI) is a condition during which glomerular filtration rate (GFR) is suddenly reduced with retaining nitrogenous wastes. It also disturbs extracellular fluid volume, electrolytes, and homeostasis in the body. In general, AKI is classified into five subgroups, including classifications of RIFLE (Risk, Injury, Failure, Loss, and End-stage renal failure), each with specific clinical and para-clinical indicators (15-17).

\section{Kidney damage in SARS-CoV2 infection}

In addition to the alveolar cells in the lungs, ACE2 (angiotensin-converting enzyme 2) has been reported in other organs including the kidney (18). Both ACE2 and dipeptidyl peptidase- 4 are expressed on renal tubular cells that help to bind SARS-CoV and MERS-CoV, respectively (19). Additionally, viral RNA has been detected in kidney tissue and urine in both infections (20). ACE2 receptors mediate entry of some types of coronaviruses into the human body cells. ACE2 receptors play an important role in the virus entrance and may cause target cells to become susceptible to COVID-19 infection $(21,22)$. The angiotensinogen protein is converted to angiotensin I by the renin hormone (released from the kidney) and subsequently to angiotensin II by angiotensin-converting enzyme (23-26), which is most commonly found in lung capillaries (22,27-32). The ACE2 is a receptor for SARSCoV and the human respiratory tract virus $\operatorname{NL63}(34,35)$. Previous studies have shown a positive association between ACE2 expression and SARS-CoV infection in vitro. Several variants of the ACE2 gene can reduce the association between ACE2 and S protein in SARS-CoV or NL63 $(32,34,36)$. Therefore, the expression level and expression pattern of the human ACE2 gene in different tissues may be crucial for the sensitivity, symptoms, and outcome of SARS-CoV-2 infection (36). It has been revealed that ACE2 is highly expressed in the brush border of proximal tubular cells and, to a lesser extent, in podocytes, but not in glomerular endothelial and mesangial cells (18). However, at the time of the outbreak of SARS, only 6\% of SARS$\mathrm{CoV}$-infected subjects experienced AKI (37). Although AKI is an uncommon feature of SARS viral disease, it has been identified as one of the fatal complications of this infection According to previous studies on SARS-CoV and MERS-CoV infections, AKI has developed in 5\% to $15 \%$ cases with high mortality rate $(60 \%-90 \%)$. Early reports suggested a lower incidence $(3 \%-9 \%)$ of AKI in those with COVID-19 (8,38). To specify that whether AKI was induced by active SARS replication in tubular cells, Lai and colleagues investigated the presence of SARS viral particles using electron transmission microscopy in renal specimens of postmortem SARS patients with AKI. They found that SARS-CoV was not detected in any of analyzed patients and assumed that kidney dysfunction is probably related to multiple organ failure (39). Another study reported the expression and distribution of ACE2 and TMPRSSs genes in the kidney cell components, and found that podocytes and proximal straight tubular cells were potential host cells targeted by SARS-CoV-2, resulting in AKI caused by the virus-induced cytopathic effect (40). During fatal pneumonia, AKI patients may be affected by synergistic assaults from the virus-induced cytopathic effect and systemic inflammatory response, especially in severe and critical cases with positive viral RNA in blood samples and massive proteinuria (40). Concerning the new coronavirus (SARS-CoV-2), studies have shown that the human kidney is a specific target for SARS-CoV-2 infection (41). Researchers evaluated 
the viral nucleocapsid protein in situ in the kidney post-mortem and found that SARS-CoV-2 antigens accumulated in kidney tubules, suggesting that SARSCoV-2 infects the human kidney directly and therefore induces AKI and contributes to viral spreading in the body (41).

\section{Clinical and laboratory findings in COVID-19 patients with renal impairment \\ Proteinuria, hematuria, inflammation and edema}

Proteinuria is one of the abnormal urinary results and is one of the diagnostic tests (42-44). A recent study conducted on 59 patients with COVID-19 found that $34 \%$ of patients developed massive albuminuria on the first day of admission, and 63\% developed proteinuria during their stay in hospital (32). Reports provided by CT scan of the kidneys showed reduced density, suggestive of swelling and edema (45). Furthermore, subjects infected with SARS-CoV-2 seem to be affected by AKI more frequently than subjects infected with SARS-CoV (45). Blood urea nitrogen was elevated in $27 \%$ overall and in two-thirds of patients who died (38). Recently, Cheng et al reported that amongst hospitalized patients with COVID-19, 44\% had proteinuria and hematuria and $26.7 \%$ had hematuria on admission. The prevalence rates of blood urea and serum creatinine were $14.1 \%$ and $15.5 \%$, respectively (38).

\section{Sepsis}

Sepsis, as the host systemic inflammatory response to infection, occurs after the invasion of microbial pathogens into the blood stream (46). Sepsis is an extreme response to infection that may cause organs failure too. Sepsis is among the principal complications and one of the leading causes of death in patients with novel coronavirus pneumonia (severe acute respiratory syndrome coronavirus 2). A cytokine storm cascade following the viral infection is the principal cause of sepsis $(46,47)$. Based on the first clinical observations, most patients with novel coronavirus pneumonia showed enhancement of pro-inflammatory cytokines, such as tumor necrosis factor alpha (TNF- $\alpha$ ), interleukin 6 (IL-6), and, interferon gamma (IFN- $\gamma$ ), with the specifications of cytokine storm (47). It is thought that sepsis is due to unregulatation of pro-inflammatory mediators forming a cytokine storm. In this condition, a lot of cytokines, such as interleukin 12 (IL-12), IL-6, interleukin-1 (IL-1), TNF- $\alpha$, IFN- $\gamma$, and interferon beta (IFN- $\beta$ ) are quickly produced in body liquids after the body is infected (48). IFN- $\beta$ induces the phosphorylation of signal transducer and activator of transcription of STAT- proteins through the activation of its own receptor, modulating the secretion of cytokines that control and adjust inflammation (49). According to studies on patients with SARS-CoV2-, it has been found that sepsis appears to be one of the mechanisms of kidney damage (50).

\section{Cytokine release syndrome}

Cytokine release syndrome (CRS) is a systemic inflammatory response that can be triggered by a variety of factors such as infections (51). Respiratory symptoms are common in patients with CRS mild cases, which may display tachypnea and cough and progress to acute respiratory distress syndrome (ARDS) with hypoxemia, and bilateral opacities on chest X-ray and dyspnea (52). Patients with severe CRS can also develop kidney failure. In severe cases, CRS can be accompanied by signs and abnormalities that resemble hemophagocytic lymphohistiocytosis or macrophage activation syndrome (53). IFN- $\gamma$, IL-6, and interleukin 10 (IL-10) are always elevated in serum of patients with CRS. IFN- $\gamma$ secretion activates immune cells in patients with CRS, including macrophages (54). The activated macrophages generate excessive amounts of additional cytokines such as IL10 , IL-6, and TNF- $\alpha$. TNF- $\alpha$ elicits flu-like symptoms such as fever, fatigue, and general malaise. Furthermore, it is responsible for the synthesis of acute-phase proteins and lung injury (51). IL-6 plays an important role in CRS pathophysiology since high levels of IL- 6 are seen in patients with CRS $(55,56)$. TNF- $\alpha$ is present in a variety of cells, including macrophages, $T$ lymphocytes, B lymphocytes, natural killer (NK) cells, neutrophils, astrocytes, and endothelial cells (57-59). The most important inducer of bacterial lipopolysaccharide (LPS) is the production of TNF- $\alpha$ and IFN- $\gamma$, which is produced by $\mathrm{T}$ and NK cells and increases the production of TNF- $\alpha$ by macrophages stimulated by bacterial LPS (60). The most important physiological action of TNF- $\alpha$ is related to the immune system. When the level of TNF- $\alpha$ in the blood increases, the contraction of the heart muscle and the smooth muscles of the arteries is inhibited, in which the blood pressure decreases and thereby sepsis occurs (61). Severe CRS occurs during some infectious diseases, including coronavirus infections (62-64). Indeed, increasing viral infection in alveolar cells results in massive recruitment of immune cells, which produce large amount of cytokines, causing multiple-organ failure that may occur in SARS-CoV infection (65). In other studies, it has been revealed that IFN- $\gamma$-induced cytokine cycling following SARS-CoV resulted in severe organ damage in SARS-CoV patients (66). The exact mechanism of kidney involvement in COVID-19 infection is still unclear. However, according to some reports, factors such as sepsis seem to cause cytokine storm syndrome or direct cellular injury due to the virus. 


\section{Treatment}

Due to severe lung injury caused by SARS-CoV2infection, mortality rate in infected patients requiring mechanical ventilation was high (67). So far, there is no specific antiviral drug to cure coronavirus. The main solution is supportive care, such as maintaining vital signs, regulating oxygen and blood pressure and reducing complications such as secondary infections or other organs failure, including kidney. Additionally, the current treatment of COVID-19 with AKI includes general and supportive management and kidney replacement therapy.

All patients with COVID-19 need to be quarantined. A study on a patient with COVID-19 showed that the use of lopinavir and ritonavir was effective. However, viral load and its probable association with clinical response should be kept in mind, since it may be due to the reduction in SARS-CoV-2 load. To prove the direct impact of lopinavir/ritonavir, more trials should be executed during treatment with COVID-19 (68). Lopinavir and ritonavir are both antiviral drugs that are classified as protease inhibitors. Both of them block the ability of HIV to bind to healthy cells and are often used in combination therapy to treat AIDS (69). Recent studies have shown that viral polymerase may be a good template for drug design of new antivirus to prevent replication of coronavirus (70). Chloroquine phosphate is another drug whose results have been well demonstrated against new coronavirus pneumonia in clinical trials in China. It is used to prevent and treat malaria and as an anti-inflammatory agent for the treatment of rheumatoid arthritis and lupus erythematosus (71). Results on the efficacy of remdesivir on a patient with COVID-19 in China was hopeful (45). Remdesivir is an antiviral drug from the family of nucleoside analogs, which was developed to treat the Ebola virus (72), however, it has been shown to have antiviral activity against other single-stranded RNA viruses, such as coronaviruses (including SARS-CoV and MERS-CoV) (73).

Treatments targeted cytokine storm like Actemra, hemoperfusion and other anti-inflammatory agents play an important role in treatment COVID19 patients, measurement of inflammatory cytokines in normal renal function and CKD patients and precise usage of these agents is being evaluated in different trials around the world (74).

\section{Conclusion}

The new coronavirus (SARS-CoV2-) can cause kidney impairment. The exact mechanism of kidney involvement in COVID-19 infection has not been clarified yet. Until now, there is no specific medication for the cure of coronavirus; hence, the primary solution is supportive care such as preservation of vital signs, regulation of oxygen and blood pressure and reduction complications such as secondary infections or other failures of the organs of the body, including the kidney.

\section{Authors' contribution}

AHD and EAD searched the literature. EAD, RA, and AHD prepared the manuscript. EAD edited the paper. All authors have equally contributed to this study, including manuscript write-up and revision. All authors critically revised and approved the final manuscript.

\section{Conflicts of interest}

The authors declared no competing interests.

\section{Ethical considerations}

Ethical issues (including plagiarism, data fabrication, double publication) have been completely observed by the authors.

\section{Funding/Support}

None.

\section{References}

1. Li Q, Guan X, Wu P, Wang X, Zhou L, Tong Y, et al. Early transmission dynamics in Wuhan, China, of novel coronavirus infected pneumonia. N Engl J Med. 2020;382:1199-207. doi: 10.1056/NEJMoa2001316

2. Yang Y, Lu Q, Liu M, Wang Y, Zhang A, Jalali N, et al. Epidemiological and clinical features of the 2019 novel coronavirus outbreak in China. Medrxiv. 2020. doi: 10.1101/2020.02.10.20021675.

3. Huang C, Wang Y, Li X, Ren L, Zhao J, Hu Y, et al. Clinical features of patients infected with 2019 novel coronavirus in Wuhan, China. Lancet. 2020;395(10223):497-506.doi: 10.1016/S0140-6736(20)30183-5.

4. Carlos WG, Dela Cruz CS, Cao B, Pasnick S, Jamil S. Novel Wuhan (2019-nCoV) Coronavirus. Am J Respir Crit Care Med. 2020;201(4):P7-P8. doi: 10.1164/rccm.2014P7.

5. Rothan HA, Byrareddy SN The epidemiology and pathogenesis of coronavirus disease (COVID-19) outbreak. J Autoimmun. 2020;109:102433. doi: 10.1016/j. jaut.2020.102433.

6. Jiang F, Deng L, Zhang L, Cai Y, Cheung CW, Xia Z. Review of the clinical characteristics of coronavirus disease 2019 (COVID-19). J Gen Intern Med. 2020 Mar 4. doi: 10.1007/ s11606-020-05762-w.

7. Chen L, Liu HG, Liu W, Liu J, Liu K, Shang J, et al. Analysis of clinical features of 29 patients with 2019 novel coronavirus pneumonia. Zhonghua Jie $\mathrm{He} \mathrm{He} \mathrm{Hu}$ Xi Za Zhi. 2020;43(3):203-208. doi: 10.3760/cma.j.is sn.1001-0939.2020.03.013.

8. Chen N, Zhou M, Dong X, Qu J, Gong F, Han Y, et al. Epidemiological and clinical characteristics of 99 cases of 2019 novel coronavirus pneumonia in Wuhan, China: a 
descriptive study. Lancet. 2020;395(10223):507-513. doi: 10.1016/S0140-6736(20)30211-7.

9. Wang D, Hu B, Hu C, Zhu F, Liu X, Zhang J, et al. Clinical Characteristics of 138 Hospitalized Patients with 2019 Novel Coronavirus-Infected Pneumonia in Wuhan, China. JAMA. 2020 Feb 7. doi: 10.1001/jama.2020.1585.

10. Coronavirus Disease 2019 (COVID-19). CDC. Available from: https://www.cdc.gov/coronavirus/2019-ncov/index. html. Accessed February 28, 2020.

11. Guan WJ, Ni ZY, Hu Y, Liang WH, Ou CQ, He JX, et al. Clinical characteristics of 2019 novel coronavirus infection in China. N Engl J Med. 2020. doi:10.1056/NEJMoa2002032.

12. Woo PC, Lau SK, Chu CM, Chan KH, Tsoi HW, Huang $\mathrm{Y}$, et al. Characterization and complete genome sequence of a novel coronavirus, coronavirus HKU1, from patients with pneumonia. J Virol. 2005;79:884-95. doi: 10.1128/ JVI.79.2.884-895.2005.

13. Song F, Shi N, Shan F, Zhang Z, Shen J, Lu H, et al. Emerging Coronavirus 2019-nCoV Pneumonia. Radiology. 2020; 295(1):210-217. doi: 10.1148/radiol.2020200274.

14. Yao XH, Li TY, He ZC, Ping YF, Liu HW, Yu SC, et al. A pathological report of three COVID-19 cases by minimally invasive autopsies. Zhonghua Bing Li Xue Za Zhi. 2020;49(0):E009. doi: 10.3760/ cma.j.cn112151-20200312-00193.

15. Mariscalco G, Lorusso R, Dominici C, Renzulli A, Sala A. Acute kidney injury: a relevant complication after cardiac surgery. Ann Thorac Surg. 2011;92(4):1539-47. doi: 10.1016/j.athoracsur.2011.04.123.

16. Parolari A, Pesce LL, Pacini D, Mazzanti V, Salis S, Sciacovelli $\mathrm{C}$, et al. Risk factors for perioperative acute kidney injury after adult cardiac surgery: role of perioperative management. Ann Thorac Surg. 2012;93(2):584-91. doi: 10.1016/j. athoracsur.2011.09.073.

17. Arora P, Kolli H, Nainani N, Nader N, Lohr J. Preventable risk factors for acute kidney injury in patients undergoing cardiac surgery. J Cardiothorac Vasc Anesth. 2012; 26(4):68797. doi: 10.1053/j.jvca.2012.03.001.

18. Ye M, Wysocki J, William J, Soler MJ, Cokic I, Batlle D. Glomerular localization and expression of angiotensinconverting enzyme 2 and angiotensin-converting enzyme: implications for albuminuria in diabetes. J Am Soc Nephrol. 2006;17(11):3067-75. doi: 10.1681/ASN.2006050423.

19. Raj VS, Mou H, Smits SL, Dekkers DH, Muller MA, Dijkman R, et al. Dipeptidyl peptidase 4 is a functional receptor for the emerging human coronavirus-EMC. Nature 2013; 495(7440):251-4. doi: 10.1038/nature12005.

20. Peiri JSM, Chu CM, Cheng VC, Chan KS, Hung IF, Poon LL, et al. Clinical progression and viral load in a community outbreak of coronavirus-associated SARS pneumonia: a prospective study. Lancet. 2003;361(9371):1767-72. doi: $10.1016 / \mathrm{s} 0140-6736(03) 13412-5$.

21. Kuba K, Imai Y, Rao S, Gao H, Guo F, Guan B, et al. A crucial role of angiotensin converting enzyme 2 (ACE2) in SARS coronavirus-induced lung injury. Nat Med. 2005; 11(8):875-9. doi: 10.1038/nm1267.

22. Zou X. Chen Ke, Zou J, Han P, Hao j, Han Z. The single- cell RNA-seq data analysis on the receptor ACE2 expression reveals the potential risk of different human organs vulnerable to Wuhan 2019-nCoV infection. Front Med. 2020 Mar 12. doi: 10.1007/s11684-020-0754-0.

23. Corvol P, Williams T. A, Soubrier F. Peptidyl dipeptidase A: angiotensin I-converting enzyme. Methods Enzymol. 1995; 248:283-305. doi: 10.1016/0076-6879(95)48020-x.

24. Boehm M, Nabel E. G. Angiotensin-converting enzyme 2-a new cardiac regulator. N Engl J Med. 2002;347(22):1795-7. doi: 10.1056/NEJMcibr022472.

25. XW P, Xu D, Zhang H, Gong H, Chen J, Ye J, et al. Identification of a potential mechanism of acute kidney injury during the covid-19 outbreak: a study based on singlecell transcriptome analysis. Intensive Care Med. 2020 Mar 31. doi: 10.1007/s00134-020-06026-1.

26. Ferrario CM, Trask AJ, Jessup JA. Advances in biochemical and functional roles of angiotensin-converting enzyme 2 and angiotensin-(1-7) in regulation of cardiovascular function. Am J Physiol Heart Circ Physiol. 2005;289:H2281-90. doi.10.1152/ajpheart.00618.2005.

27. Zhao Y, Zhao Z, Wang Y, Zhou Y, Ma Y, Zuo W. Singlecell RNA expression profiling of ACE2, the putative receptor of Wuhan 2019-nCov. bioRxiv. 2020. doi: 10.1101/2020.01.26.919985.

28. Zhang H, Kang Z, Gong H, Xu D, Wang J, Li Z, et al. The digestive system is a potential route of 2019-nCov infection: a bioinformatics analysis based on single-cell transcriptomes. bioRxiv 2020. doi:10.1101/2020.01.30.927806.

29. Santos RAS, Oudit GY, Verano-Braga T, Canta G, Steckelings UM, Bader M. The renin-angiotensin system: going beyond the classical paradigms. Am J Physiol Heart Circ Physiol. 2019;316(5):H958-70.

30. Ren X. Glende J, Al-Falah M, de Vries V, Schwegmann-Wessels $\mathrm{C}, \mathrm{Qu}$ X, et al. Analysis of ACE2 in polarized epithelial cells: surface expression and function as receptor for severe acute respiratory syndrome-associated coronavirus. J Gen Virol 2006;87(Pt 6):1691-5. doi: 10.1099/vir.0.81749-0.

31. Qiu Y, Zhao YB, Wang Q, Li JY, Zhou ZJ, Liao CH, et al. Predicting the angiotensin converting enzyme 2 (ACE2) utilizing capability as the receptor of SARS-CoV-2. Microbes Infect. 2020 Mar 19. doi: 10.1016/j.micinf.2020.03.003.

32. Li Z, Wu M, Guo J, Yao J, Guo J, Liaox X, et al. Caution on kidney dysfunctions of 2019-nCoV patients. Medrxiv 2020. doi: 10.1101/2020.02.08.20021212.

33. Harmer D, Gilbert M, Borman R, Clark K. L. Quantitative mRNA expression profiling of ACE 2, a novel homologue of angiotensin converting enzyme. FEBS Lett. 2020;532:10710.

34. Hofmann H, Pyrc K, Van der Hoek L, Geier M, Berkhout B, Pohlmann S. Human coronavirus NL63 employs the severe acute respiratory syndrome coronavirus receptor for cellular entry. Proc Natl Acad Sci U S A. 2005;102(22):7988-93. doi: 10.1073/pnas.0409465102.

35. Chai X, Hu L, Zhang Y, Han W, Lu Z, Ke A, et al. Specific ACE2 expression in cholangiocytes may cause liver damage after 2019-nCoV infection. bioRxiv. 2020. doi: 10.1

36. Zhou P, Yang XL, Wang XG, Hu B, Zhang L, Zhang W, et al. 
A pneumonia outbreak associated with a new coronavirus of probable bat origin. Nature 2020;579(7798):270-273. doi: 10.1038/s41586-020-2012-7.

37. Chu KH, Tsang WK, Tang CS, Lam MF, Lai FM, To KF, et al. Acute renal impairment in coronavirus-associated severe acute respiratory syndrome. Kidney Int 2005;67(2):698-705. doi: 10.1111/j.1523-1755.2005.67130.x.

38. Cheng Y, Luo R, Wang K, Zhang M, Wang Z, Dong L, et al. Kidney impairment is associated with in-hospital death of COVID-19 patients. Medrxiv. 2020. doi:10.1101/2020.02. 18.20023242 .

39. Chu WM. Tumor necrosis factor. Cancer Lett. 2013; $328(2): 222-5$.

40. Xu H, Zhong L, Deng J, Peng J, Dan H, Zeng X, et al. High expression of ACE2 receptor of 2019-nCoV on the epithelial cells of oral mucosa. Int J Oral Sci. 2020;12;8.

41. Diao B, Feng Z, Wang C, Wang H, Liu L, Wang C, et al. Human kidney is a target for novel severe acute respiratory syndrome coronavirus 2 (SARS-CoV-2) infection. Medrxiv 2020. doi: $10.1101 / 2020.03 .04 .20031120$.

42. Methven S, MacGregor MS, Traynor JP, O’Reilly DS, Deighan CJ .Assessing proteinuria in chronic kidney disease: protein-creatinine ratio versus albumin-creatinine ratio. Nephrol Dial Transplant. 2010;25:2991-6.

43. Voskarides K, Stefanou C, Pieri M, Demosthenous P, Felekkis $\mathrm{K}$, Arsali $\mathrm{M}$, et al. A functional variant in $\mathrm{NEPH} 3$ gene confers high risk of renal failure in primary hematuric glomerulopathies. Evidence for predisposition to micro albuminuria in the general population. PLoS One 2017;12:e0174274. doi: 10.1371/journal.pone.0174274.

44. Lim AK, Brown S, Simpson I, Dowling JP. Acute kidney injury due to glomerular hematuria and obstructive erythrocyte casts associated with thrombocytopenia and thin basement membrane disease: a case report. BMC Nephrol 2015;16:180. doi: 10.1186/s12882-015-0176-4.

45. Naicker S, Yang CW, Hwang SJ, Liu BC, Chen JH, Jha V. The Novel Coronavirus 2019 epidemic and kidneys. Kidney Int. 2020 Mar 7. doi: 10.1016/j.kint.2020.03.001.

46. National Health Committee, China's State Administration of Traditional Chinese Medicine. Novel Coronavirus Pneumonia Diagnosis and Treatment Plan (Sixth ed. trial version) [EB/OL]; 2020. http://www.nhc.gov.cn/yzygj/ s7653p/202002/8334a8326dd94d329df351d7da8aefc2. shtml. Accessed 2020 Feb 18.

47. Jin GY, Jin LL, Zheng J, He BJ. Advantages of antiinflammatory acupuncture in treating sepsis of novel coronavirus pneumonia. World J Tradit Chin Med. 2020. doi: 10.4103/wjtcm.wjtcm_12_20.

48. Boomer JS, To K, Chang KC, Takasu O, Osborne DF, Walton $\mathrm{AH}$, et al. Immunosuppression in patients who die of sepsis and multiple organ failure. JAMA. 2011;306:2594605. doi: 10.1001/jama.2011.1829.

49. Dhib-Jalbut S, Marks,S. Interferon-beta mechanisms of action in multiple sclerosis. Neurology. 2010;74:S17-S24. doi: 10.1212/WNL.0b013e3181c97d99.

50. Expert Team of Chinese Society of Nephrology. Expert consensus on diagnosis and treatment of 2019 novel coronavirus (2019 - $\mathrm{nCoV}$ ) infection with acute kidney injury. Chin J Nephrol. 2020. doi: 10.3760/ cma.j.cn441217-20200222-00035.

51. Hunter CA, Jones SA. IL-6 as a keystone cytokine in health and disease. Nat Immunol. 2015;16(5):448-457. doi: 10.1038/ni.3153.

52. Hay KA, Hanafi L-A, Li D, Gust J, Liles WC, Werfel MM, et al. Kinetics and biomarkers of severe cytokine release syndrome after CD19 chimeric antigen receptor-modified T cell therapy. Blood. 2017;130(21):2295-2306. doi: 10.1182/ blood-2017-06-793141.

53. Kantarjian H, Stein A, Gokbuget N, Fielding AK, Schuh AC, Ribera JM, et al. Blinatumomab versus chemotherapy for advanced acute lymphoblastic leukemia. N Engl J Med. 2017;376:836-47. doi: 10.1056/NEJMoa1609783.

54. Shimabukuro-Vornhagen A, Godel P, Subklewe M, Joachim Stemmler H, Anton Schloßer H, Schlaak M, Kochanek M, Boll B, et al. Cytokine release syndrome. J Immunother Cancer. 2018;6:56. doi:10.1186/s40425-018-0343-9.

55. Frey NV, Porter DL. Cytokine release syndrome with novel therapeutics for acute lymphoblastic leukemia. Hematology Am Soc Hematol Educ Program 2016;2016(1):567-72. doi: 10.1182/asheducation-2016.1.567.

56. Teachey DT, Rheingold SR, Maude SL, Zugmaier G, Barrett DM, Seif AE, et al. Cytokine release syndrome after blinatumomab treatment related to abnormal macrophage activation and ameliorated with cytokine-directed therapy. Blood. 2013;121(26):5154-7.

57. Idriss HT, Naismith JH. TNF $\alpha$ and the TNF receptor superfamily: Structure-function relationship(s). Microsc Res Tech. 2000;50(3):184-95. doi: 10.1002/1097-0029(20000801)50:3<184::AIDJEMT2>3.0. CO;2- $\mathrm{H}$.

58. Beyaert R, Fiers W. Molecular mechanisms of tumor necrosis factor-induced cytotoxicity. What we do understand and what we do not. FEBS Lett. 1994;340(1-2):9-16. doi: 10.1016/0014-5793(94)80163-0.

59. Chen Q, Wang H, Liu Y, Song Y, Lai L, Han Q, Cao X, Wang Q. Inducible microRNA-223 down-regulation promotes TLR-triggered IL-6 and IL-1b production in macrophages by targeting STAT3. PLoS One. 2012;7:e42971.

60. Abbas AK, Lichtman AH, Pober JS. Cellular and Molecular Immunology. 7th ed. Philadelphia, PA: Elsevier/Saunders; 2011.

61. Pfeffer K. Biological functions of tumor necrosis factor cytokines and their receptors. Cytokine Growth Factor Rev. 2003;14(3-4):185-91. doi: 10.1016/s1359-6101(03)000224.

62. Lee DW, Gardner R, Porter DL, Louis CU, Ahmed N, Jensen $\mathrm{M}$, et al. Current concepts in the diagnosis and management of cytokine release syndrome. Blood. 2014;124(2):188-95. doi: 10.1182/blood-2014-05-552729.

63. Liu Q, Zhou Y-h, Yang Z (2013-04-20). The cytokine storm of severe influenza and development of immunomodulatory therapy. Cell Mol Immunol. 2015;13(1):3-10. doi: 10.1038/ cmi.2015.74.

64. Liu Z, Xiao X, Wei X, Li J, Yang J, Tan H, et al. Composition 
and divergence of coronavirus spike proteins and host ACE2 receptors predict potential intermediate hosts of SARS CoV-2. J Med Virol. 2020 Feb 26. doi: 10.1002/jmv.25726.

65. Tisoncik JR, Korth MJ, Simmons CP, Farrar J, Martin TR, Katze MG. Into the eye of the cytokine storm. Microbiol Mol Biol Rev. 2012;76(1):16-32. doi: 10.1128/MMBR.0501511.

66. Huang KJ, Su IJ, Theron M, Wu YC, Lai SK, Liu CC, et al. An interferon-gamma-related cytokine storm in SARS patients. J Med Virol. 2005;75(2):185-94. doi: 10.1002/ jmv.20255.

67. Alshahrani MS, Sindi A, Alshamsi F, et al. Extracorporeal Membrane Oxygenation for Severe Middle East Respiratory Syndrome Coronavirus. Ann Intensive Care. 2018;8(1):3. doi: 10.1186/s13613-017-0350-x.

68. Lim J, Jeon S, Shin HY, Kim MJ, Seong YM, Lee WJ, et al. Case of the Index Patient Who Caused Tertiary Transmission of Coronavirus Disease 2019 in Korea: The Application of Lopinavir/Ritonavir for the Treatment of COVID-19 Pneumonia Monitored By Quantitative RT-PCR. J Korean Med Sci. 2020;35(6):e79. doi: 10.3346/jkms.2020.35.e79.

69. Chandwani A, Shuter J. Lopinavir/ritonavir in the treatment of HIV-1 infection: a review. Ther Clin Risk Manag.
2008;4(5):1023-33. doi: 10.2147/TCRM.S3285.

70. Kirchdoerfer RN, Ward AB. Structure Of The SARS-Cov Nsp12 Polymerase Bound To Nsp7 And Nsp8 Co-Factors. Nat Commun. 2019;10(1):2342. doi: 10.1038/s41467-01910280-3.

71. Gao J, Tian Z, Yang X. Breakthrough: chloroquine phosphate has shown apparent efficacy in treatment Of COVID-19 associated pneumonia in clinical studies. Biosci Trends. 2020;14(1):72-73. doi: 10.5582/bst.2020.01047.

72. Warren TK, Jordan R, Lo MK, Ray AS, Mackman RL, Soloveva $\mathrm{V}$, et al. Therapeutic efficacy of the small molecule GS-5734 against Ebola virus in rhesus monkeys. Nature. 2016;531(7594):381-5. doi: 10.1038/nature17180.

73. Sheehan TP, Sims AC, Graham RL, Menachery VD, Gralinski LE, Case JB, et al. Broad-spectrum antiviral GS5734 inhibits both epidemic and zoonotic coronaviruses. Sci Transl Med. 2017;9(396):eaal3653. doi: 10.1126/ scitranslmed.aal3653.

74. Argani H, Alirezaei A, Ghorbanihaghjo A, Azizi T, Asgharpour $\mathrm{M}$, et al. Comparing the serum levels of adipocytokines in the renal transplant recipients and healthy individuals: a casecontrol study. Iran Red Crescent Med J. 2018;20(3):e62674. doi: $10.5812 /$ ircmj.62674.

Copyright (C) 2020 The Author(s); Published by Society of Diabetic Nephropathy Prevention. This is an open-access article distributed under the terms of the Creative Commons Attribution License (http://creativecommons.org/licenses/by/4.0), which permits unrestricted use, distribution, and reproduction in any medium, provided the original work is properly cited. 